\title{
THREE NEW TREES FROM TABASCO AND CAMPECHE (a)
}

C. L. Lundell

PITHECOLOBIUM CAMPECHENSE Lundell, sp. nov.

Arbor. Stipulae subulatae, usque ad $3 \mathrm{mn}$. longae. Petioli usque ad $2.3 \mathrm{~cm}$. longi. Pinnae 1-jugae. Foliola 1-juga, oblonga, chartacea, basi barbata, apice rotundata vel emarginata. Inflorescentiae spicatae, adpresse puberulae; bracteae minutae. Jalyx 1--1.3 mm. longus. Cor olla $4 \mathrm{~mm}$. longa.

A tree 7 to $10 \mathrm{~m}$. high, 30 to $60 \mathrm{~cm}$. in diam., branchlets rather slender, glabrous, striate. Stipular spines minute, stout, less than $3 \mathrm{~mm}$. long. Petioles up to $2.3 \mathrm{~cm}$. long, often less than $1 \mathrm{~cm}$. long, glabrous, slender, with a discoid apical gland. Pinnae 1 pair. Leaflets 1-pair, obliquely oblong, 2 to $4.3 \mathrm{~cm}$. long, up to $1.9 \mathrm{~cm}$. wide, chartaceous, barbate at base beneath, entirely glabrous otherwise, apex rounded or emarginate, both surfaces reticulate-veined. Spikes up to $4 \mathrm{~cm}$. long, borne in panicles, puberulent; bractlets minute, less than half the length of calyx, persistent. Flowers sessile. Valyx appressed-puberulent, 1 to $1.3 \mathrm{~mm}$. long. Corolla appressed-puberul ent, $4 \mathrm{~mm}$. long. Stamen-tube shortly exserted. Ovary subsessile, covered with appressed hairs.

VEXICO: Campeche, Palizada, in "swamp side forest", July 25--28, 1939, Eizi Matuda 3866 (type in the University of Michigan Herbarium); vernacular name "tinta".

From P. lanceolatum (H. \& B.) Benth., to which it is allied, P. compechense differs in having minute stipular spines, much shorter flower spikes, and smaller calyx and corolla. The fruits are not known.

EUGENIA BALANCANENSIS Lundell, sp. nov.

Arbor parva, glabra. Folia petiolata, chartacea, ovatolanceolata, apice attenuata, obtuse acuminata, basi acuta. Inflorescentiae racemosae, axillares, usque ad $1.7 \mathrm{~cm}$. longae. Pedicelli usque ad $6 \mathrm{~mm}$. longi. Petala oblonga.

Tree, $4 \mathrm{~m}$. high, $15 \mathrm{~cm}$. diam., glabrous throughout excepting the sparsely puberulent buds. 3ranchlets slender, compressed at first, glandular-punctate. Petioles short, canaliculate, 3 to $6 \mathrm{~mm}$. long. Leaf-blades thin, chartaceous, punctate, concolorous or slightly paler beneath, ovatelanceolate, 4 to $9.5 \mathrm{~cm}$. long, 1.3 to $3.5 \mathrm{~cm}$. wide, apex attenuate, obtusely acuninate, base acute, costa nearly plane above, inconspicuously elevated beneath, the main lateral veins 6 to 10 on each side, anastomosing into a submarginal vein, prominul ous beneath. Inflorescence racemose, the rac481 
emes axillary, solitary or fasciculate, up to $1.7 \mathrm{~cm}$. 1 ong with a short rachis; the rachis and pedicels glandularpunctate. Pedicels slender, up to $6 \mathrm{~mm}$. long. Calyx small, the tube subglobose, less than $1 \mathrm{~mm}$. long, 4-lobed, the lobes rounded, unequal, the larger up to $1.5 \mathrm{~mm}$. long, minutely ciliolate. Petals oblong, up to $3.2 \mathrm{~mm}$. long, conspicuously glandular-punctate.

VIEXICO: Tabasco, San Isidro near Balancan, in advanced forest, June 7--11, 1939, Eizi Matuda 3361 (type in the University of Michigan Herbarium).

EUGENIA TABASCENSIS Lundell, sp. nov.

Arbor parva, ramulis albido-sericeis. Folia petiolata, chartacea, anguste elliptico-oblonga, apice caudato-acuminata, basi cuneata, sericea vel subglabra. Inflorescentiae racemosae, axillares, fasciculatae, usque ad $4.5 \mathrm{~cm}$. longae. Pedicelli usque ad $6.5 \mathrm{~mm}$. longi. Fetala obovata vel elliptica, $2.6--3.4 \mathrm{~mm}$. longa, ciliolata.

A small tree. Branchlets slender, whitish-sericeous, at first compressed and sulcate at the nodes, reddish. Leaves attenuate at the base into short, slender, canaliculate, sparingly sericeous petioles up to $5 \mathrm{~mm}$. long. Leaf-blades chartaceous, narrowly elliptic-oblong, 3 to $7.5 \mathrm{~cm}$. l ong, 1 to $3 \mathrm{~cm}$. wide, apex caudate-acuminate, the cusp obtuse, base cuneate, punctate, sparingly sericeous on both surfaces at first, at length with only a few hairs persisting along the costa, the midvein impressed above, elevated beneath, the lateral veins numerous, approximate, prominul ous below, less evident above, reticulate, merging into a prominulous submarginal vein. Inflorescence densely sericeous, racemose, the racemes axillary, usually fasciculate, up to $4.5 \mathrm{~cm}$. long, sessile or pedunculate, the rachis slender. Pedicels slender, up to $6.5 \mathrm{~mm}$. long. Jalvx whitish-sericeous, 4lobed, the lobes sparingly puberulent on both surfaces, 1 to $1.3 \mathrm{~mm}$. long. Petals obovate or elliptic, 2.6 to $3.4 \mathrm{~mm}$. long, ciliolate, glabrous otherwise, punctate; receptacle puberulent.

MEXICO: Tabasco, Boca Cerro on the Usumacinta River above Tenosique, on limestone, July 1--5, 1939, Eizi Matuda 2561 (type in the University of Michigan Herbarium).

The species is related to Eugenia yucatanensis Standl. and E. cocquericotensis Lundell.

(a) Papers from the University of Michigan Herbarium. 


\section{$2 \mathrm{BHL}$ Biodiversity Heritage Library}

Lundell, Cyrus Longworth. 1941. "Three new trees from Tabasco and

Campeche." Phytologia 1, 481-482. https://doi.org/10.5962/bhl.part.19010.

View This Item Online: https://www.biodiversitylibrary.org/item/48981

DOI: https://doi.org/10.5962/bhl.part.19010

Permalink: https://www.biodiversitylibrary.org/partpdf/19010

\section{Holding Institution}

New York Botanical Garden, LuEsther T. Mertz Library

\section{Sponsored by}

The LuEsther T Mertz Library, the New York Botanical Garden

\section{Copyright \& Reuse}

Copyright Status: In copyright. Digitized with the permission of the rights holder.

Rights Holder: Phytologia

License: http://creativecommons.org/licenses/by-nc-sa/3.0/

Rights: https://biodiversitylibrary.org/permissions

This document was created from content at the Biodiversity Heritage Library, the world's largest open access digital library for biodiversity literature and archives. Visit BHL at https://www.biodiversitylibrary.org. 